\title{
気象庁マグニチュードによる震源スペクトルのスケーリング則 SCALING RELATIONS FOR EARTHQUAKE SOURCE SPECTRUM AND JMA MAGNITUDE
}

\author{
福島美光*, 田中貞二** \\ Yoshimitsu FUKUSHIMA and Teiji TANAKA
}

\begin{abstract}
Based on the $\omega^{-2}$ model, a relation between $M_{0}$ and $M_{J}$ was derived from the data of 63 events whose $M_{J}$ are ranging from 3.9 to 8.2. Further, the theoretical scaling law of the source spectrum obtained from the relation was approximated with the $M_{J}^{2}$ term of the attenuation relation. This approximation was confirmed from the strong-motion accelerograms from the large events occurred in the northern Japan.
\end{abstract}

Keywords : source spectrum, $\omega^{-2}$ model, attenuation relation, JMA magnitude, scaling law, regression analysis

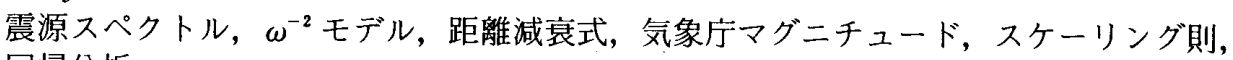
回帰分析

1.はじめに

建築物への入力地震動は, 一般に震源特性, 伝播特性, およびサイト近傍の地盤特性の三つの要素で評価され る。このうち地盤の増幅特性は, 大きな不整形性がない 限り，一次元波動論で評価されている。その場合，地盤 の減衰特性が不確定要因として問題となるが, “近年, 減 衰定数の周波数低存性の研究が進み, 評価精度がかなり

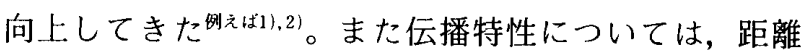
減衰特性としての評価が最近まで精力的に続けられてい る甽え(\{3\},4)。一方, 震源特性の評価は, $\mathrm{Aki}^{5 !} か ゙ \omega^{-2}$ モデ ルによって地震波スペクトルと地震マグニチュードの間 の理論的なスケーリング則を提出して以来, 断層パラ メー夕間の相似則の確立 ${ }^{61,7 !}$, 観測記録による $\omega^{-2}$ モデ ルの追認刚えは181ー10)など，理学分野において豊富な知見が 蓄積されてきた。 $\omega^{-2}$ モデルは, 観測記録のスペクトル 特性をよく説明することから, 中, 小地震の記録波形を 経験的グリーン関数とする，いわゆる波形合成法による 強震動予測にも採用されている甽えは111, 12\}。

一方, 工学分野における各種の地震動評価手法におい ては, 実用上の観点から地震の大きさとして気象庁マグ ニチュード $M_{J}$ を用いる場合が多いが, 震源理論との対 応は必ずしも明確にされていない13i。

以上の観点から本研究では, 入力地震動評価に用いら れる距離減衰式におけるマグニチュード項の物理的意味 を明らかにするとともに, 震源特性の評価指標としての
気象叮マグニチュード $M_{J}$ の $\omega^{-2}$ モデルによるスケーリ ング則を検討した。

\section{2. 地震動評価式の問題点}

地震動振幅の評価式には種々の関数形が用いられて いるが, 実体波の場合, 評価式は地震のマグニチュー ド $M$ と距離 $X$ を説明変数として (1) 式で表され る刚え゙は13) - 15)。

$$
\log A(T)=a(T) \cdot M-b(T) \cdot X-\log X+c(T)
$$

ここで, $A(T)$ : 周期 $T$ における振幅, $a(T)$ : マグニ チュード係数, $b(T)$ : 距離係数, $c(T)$ : 定数項であり, $a(T), b(T), c(T)$ は観測デー夕の重回帰分析によって 求められる。

今，Mの大きさによる影響だけを考えるため，同じ 地域で発生した大きさの異なる二つの地震 $M_{i}, M_{j}$ が, 同じ観測点で観測されたとする。 $r(T)$ を $M_{i}, M_{j}$ の地震 のスペクトル振幅 $A_{i}(T), A_{j}(T)$ の比 $r(T)=$ $A_{i}(T) / A_{j}(T)$ とおくと, マグニチュード係数 $a(T)$ は重 回帰分析によらずに,

$$
a(T)=\log r(T) /\left(M_{i}-M_{j}\right) \cdots
$$

と求めることができる。すなわち, $a(T)$ は $M_{i}, M_{j}$ のい かなる組合せに対しても一つの定数となる。

一方， $\omega^{-2}$ モデルにおける変位フーリエスペクトル $D(T)(\mathrm{cm} \cdot \mathrm{sec})$ は， $T_{0}$ をコーナー周期として $(3)$ 式 
で,また加速度スペクトル $A(T)(\mathrm{cm} / \mathrm{sec})$ は (4) 式 で表すことができる。

$$
\begin{aligned}
& D(T)=R M_{o} / 4 \pi X \mu \beta /\left\{1+\left(T_{0} / T\right)^{2}\right\} \\
& A(T)=(2 \pi / T)^{2} D(T) \cdots \cdots \cdots \ldots \ldots \ldots \ldots \ldots \ldots . . .
\end{aligned}
$$

ここで, $R: \mathrm{S}$ 波のラジエーションパターン, $M_{0}:$ 地 震モーメント (dyne $\cdot \mathrm{cm}), \mu$ : 剛性率 $\left(\right.$ dyne $\left./ \mathrm{cm}^{2}\right), \beta$ : せん断波速度 $(\mathrm{km} / \mathrm{sec})$ である。 $M$ による震源スぺ クトルの変化を $M$ に関するスケーリングと呼ぶことに すると, $(2 \pi / T)$ は $M$ にかかわらない項なので, 加速 度スペクトルの $M$ に関するスケーリングと変位スペク トルの $M$ に関するスケーリングは全く同様となる ${ }^{16+}$ の で本論では一貫して変位スペクトルを扱うこととする。 変位フーリエスペクトルは, Fig. 1(a) で模式的に示す ように，規模の異なる地震 $M_{1}, M_{2}, M_{3}$ のそれぞれに対 してコーナ一周期 $T_{1}, T_{2}, T_{3}$ が存在し, 短周期側では コーナー周期まで $\log T^{2}$ に比例して増加し, 長周期側

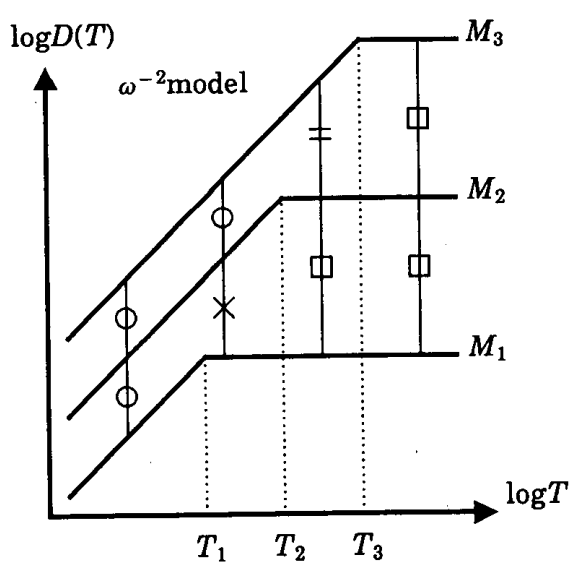

(a) Displacement source spectrum of $\omega^{-2}$ model.

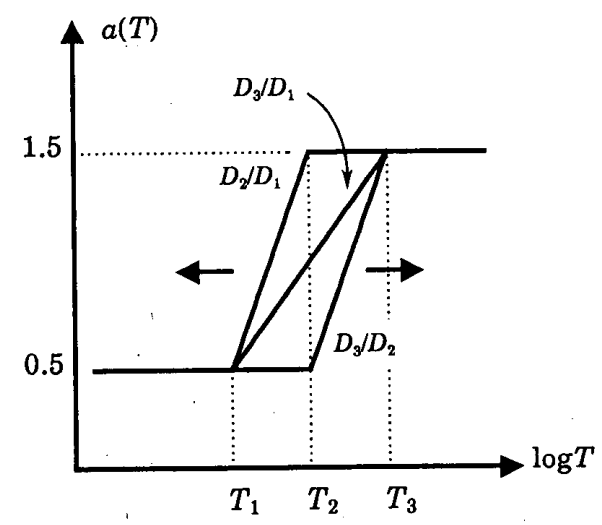

(b) Magnitude coefficients derived from source spectrum ratio for $\omega^{-2}$ model.

Fig. 1 Schematic figures of source spectra of $\omega^{-2}$ model and the magnitude coefficients derived from the source spectrum ratio. Individual symbols indicate spaces between the spectra. $T_{1}, T_{2}$ and $T_{3}$ are corner periods, $M_{1}, M_{2}$ and $M_{3}$ are earthquake magnitudes, and $D_{1}, D_{2}$ and $D_{3}$ are the source spectra for the earthquakes with magnitude $M_{1}, M_{2}$ and $M_{3}$.
では一定值になる。したがって Fig.1(b) のように，ス ペクトル比 $r(T)$ から求まるマグニチュード係数 $a(T)$ は $M$ の大きさの組合せによって様々に変化する。

\section{3. $\boldsymbol{M}^{2}$ 項を導入した地震動評価式の理論的考察}

（1）式に対して， $M^{2}$ 項を導入して（5）式のよう な形の回帰式で地震動加速度の応答スペクトルや最大振 幅を評価した研究がある刚えば14),17), 18)。

$$
\begin{aligned}
\log A(T)= & a_{1}(T) \cdot M^{2}+a_{2}(T) \cdot M \\
& -b(T) \cdot X-\log X+c(T) \cdots
\end{aligned}
$$

ここで, $a_{1}(T), a_{2}(T)$ は回帰係数である。そこで，まず

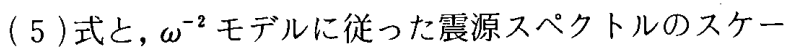
リング則がどのような関係になっているのかを検討し た。

（3）式の対数をとると,

$$
\begin{aligned}
\log D(T)= & \log M_{0}-\log X+\log (R / 4 \pi \mu \beta) \\
& -\log \left\{1+\left(T_{0} / T\right)^{2}\right\} \ldots \ldots \ldots \cdots \cdots \cdots(6) \cdots \cdots \cdots
\end{aligned}
$$

コーナ一周期 $T_{0}(\mathrm{sec})$ は, 断層面積を $S\left(\mathrm{~km}^{2}\right)$ とすれ ば, 断層モデルの仮定条件により次のような複数の評価 式がある191 21)。

$$
\begin{aligned}
& T_{0}=2 \pi \sqrt{S} / 2.34 \sqrt{\pi} \beta \quad(\text { Brune, } 1970) \cdots(7) \\
& T_{0}=2 \pi \sqrt{S} / \sqrt{14.8} \beta \quad(\text { Savage, } 1972) \cdots(8) \\
& T_{0}=2 \pi \sqrt{S} / 1.85 \sqrt{\pi} \beta
\end{aligned}
$$

(Sato and Hirasawa, 1973) $\cdots(9)$

仮に $\beta=3.8(\mathrm{~km} / \mathrm{sec})$ と仮定すれば（7) （9）式の コーナ一周期は近似的に（10）式で表すことができる。

$$
T_{0}^{2} \simeq 0.2 S
$$

さらに, $M$ と $M_{o}, M$ と $S$ の関係として $\mathrm{Sato}^{22)}$ による 次式

$$
\begin{aligned}
& \log M_{o}=1.5 M+16.2 \\
& \log S=M-4.07 \ldots \ldots
\end{aligned}
$$

が成り立つとして，（6）式に（10，（11），(12）式を代 入すると,

$$
\begin{aligned}
\log D(T)= & 0.5 M-\log \left(1+T^{2} / 0.2 \cdot 10^{M-4.07}\right) \\
& +\log (\pi R / \mu \beta X) \\
& +21.0+\log \left(T^{2} / 4 \pi^{2}\right) \cdots \cdots \cdots \cdots \cdots
\end{aligned}
$$

となる。ここで, (13) 式の $M$ に関する項を

$$
\begin{aligned}
& 0.5 M-\log \left\{1+T^{2} /\left(0.2 \cdot 10^{M-4.07}\right)\right\} \\
& =0.5 M-g(T, M) \text {. }
\end{aligned}
$$

とおく。(14) 式の $M$ に関する非線形項 $g(T, M)$ を Fig. 2 に実線で, また $g(T, M)$ を $M$ の二次式で近似し たものを破線で示した。図から $g(T, M)$ は周期が長い ほど非線形性が強くなることがわかる。しかし， $g(T$, $M)$ の值は $\boldsymbol{M} \cdot$ が大きいほど比例部分の $0.5 \boldsymbol{M}$ に比べて 小さく, 相対的に $M^{2}$ 項で近似される非線形項の影響は 小さくなる。すなわち $M$ に関する項は， $\omega^{-2}$ モデルに 従うとすれば非線形性を有し，スペクトルの評価式を $M$ の二次式で表す根拠を与える。しかしながらその影 


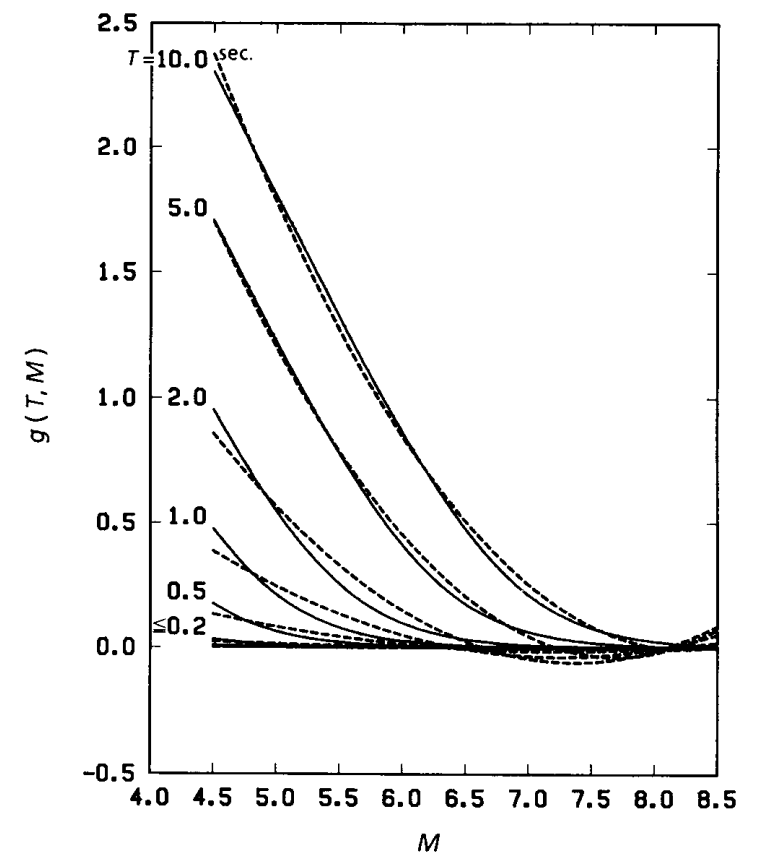

Fig. 2 Non linear term of source spectrum $g(T, M)$ in equation (14) (solid line). Broken lines are approximate relations described by $M^{2}$ term.

\section{響は大きくないといえる。}

Joyner and Boore ${ }^{14}$ は短周期で決まる最大加速度の 距離减衰式をモーメントマグニチュード $\boldsymbol{M}_{\boldsymbol{w}}$ の二次式で 評価し，結果として一次式で十分であったとしており， 彼らの研究結果を理論的に裹付けるものと考えられる。

\section{4. $M_{J}$ による $\omega^{-2}$ モデルのスケーリング則}

(14）式から考えられる $M^{2}$ 項の係数 $a_{1}(T)$ は負にな るが, Kamiyama ${ }^{17)}$ が求めた $M^{2}$ 項の係数は正で，逆セ ンスとなっている。これは $g(T, M)$ を求める際に用い た（11）式が Kanamori ${ }^{23)}$ による $M_{w}$ と $M_{o}$ の関係式之 数值的にほとんよ゙等しく，(11）式の $M$ は $M_{w}$ に対応す るとみなせるのに対して，Kamiyama ${ }^{17)}$ が用いた $M$ は 気象庁マグニチュード $M_{J}$ であり，その決定周期の違い が原因しているものと思われる。すなわち，MJ決定 周期は 5 秒以下数秒付近であり，我々が評価の対象とす る規模の地震のコーナー周期と微妙にかかわってくる。

日本において地震動を評価する場合， $M_{\mathrm{J}}$ は地震規模 を表す最も便利な指標であり，MJ外により適切な指

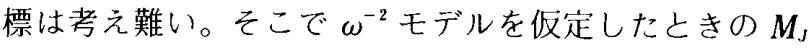
による震源スペクトルのスケーリング則を検討する。

いま $M_{J}$ の決定周期を 5 秒と仮定すると, 周期 5 秒に おける変位フーリエスペクトル振幅 $D(5)$ と坪井式 ${ }^{24}$ の 最大振幅 $A$ (micron) の関係は $\mathrm{Aki}^{5)}$ によれば (15) 式 のように表せる。

$$
D(5)=C_{0} \cdot A \cdot t^{k}
$$

ここに, $C_{0}$ : 定数項, $t$ : 継続時間, $k$ : 継続時間の寄 与率で，０（表面波の上うに分散性の強い時刻歴のとき
は継続時間にかかわらず 1 波でスペクトル振幅が決まっ てしまう) 加ら（有限長の定常振動のときスペクトル 振幅は継続時間に比例する) までの值をとる。また継続 時間 $t$ は, $p, q$ は定数として $M_{J}$ によって一次近似的 に（16）式で表せる25!。

$\log t=p \cdot M_{J}+q$

（15）式の対数をとると

$\log D(5)=\log C_{0}+\log A+k \cdot p \cdot M_{J}+k \cdot q$

また，(17）式に, 坪井式 $(\Delta$ : 震央距離),

$M_{J}=1.73 \log \Delta+\log A-0.83$

および $(6)$ 式の関係を代入すると

$$
\begin{aligned}
& \log M_{o}-\log 4 \pi X \mu \beta-\log \left(1+T_{0}^{2} / 5^{2}\right) \\
& =M_{J}-1.73 \log \Delta+0.83+k \cdot p \cdot M_{J}
\end{aligned}
$$$$
+\log C_{0}+k \cdot q-\log R
$$

となる。断層面樍 $S$ と $M_{o}$ の関係は, (11), (12) 式か ら（20）式のように表される。

$\log S=\log M_{0}^{2 / 3}-14.9$

したがって（10）式は

$$
T_{0}^{2} \simeq 0.2 S=10^{-15.6} \cdot M_{o}^{2 / 3}
$$

と表せる。（21）式を（19）式に代入して，ある一定の 距離で考えれば, 距離に関する項は定数項之なるので

(19) 式は

$$
\begin{aligned}
& \log \left(\boldsymbol{M}_{o}^{-1}+10^{-17} \boldsymbol{M}_{o}^{-1 / 3}\right)=-(1+k \cdot p) \cdot \boldsymbol{M}_{J} \\
& +(1.73 \log \Delta-0.83-\log 4 \pi X \mu \beta \\
& \left.-\log C_{0}-k \cdot q+\log R\right) \\
& =-(1+k \cdot p) \cdot M_{\jmath}+C
\end{aligned}
$$

上なる。ただし $C$ は定数項である。

「断層パラメター・ハンドブック」 ${ }^{26 !}$ から 1927 年以 後, 深さ $60 \mathrm{~km}$ 以浅の 63 地震を選び, 回帰分析により $M_{J}$ の係数および定数項を求めると（23）式が得られる。 なお，カッコ内の数值は，95\%の信頼限界27〕表す。

$$
\begin{aligned}
& \log \left(\boldsymbol{M}_{o}^{-1}+10^{-17} \boldsymbol{M}_{0}^{-1 / 3}\right)=-1.10( \pm 0.06) \boldsymbol{M}_{J} \\
& -17.92( \pm 0.42)
\end{aligned}
$$

(23) 式の $M_{J}$ と $M_{o}$ の関係を用いて, 距離 $100 \mathrm{~km}$ に おける変位フーリエスペクトルを画くと Fig. 3 のよう になる。スペクトルの振幅レベルは $M$ 、を決定する周期 5 秒において等間隔になるが，他の周期では間隔がまち まちで，かなり複雑である。次に， $M_{J}$ を横軸に，变位フー リ工振幅を縦軸にとり, 周期ごとの $M_{\mathrm{J}}$ によるスペクト ル振幅の增加を示すと Fig. 4 が得られる。スペクトル 振幅は周期 5 秒付近ではほぼ線形に增加するが，5秒よ り長い周期では下に凸の二次曲線，5秒より短周期で 0.1 秒程度までは三次曲線, さらに短周期では再び下に 凸の二次曲線で近似できる。しかしながら，M⿻が 5.5 程度以上に限定するならば，下に凸の二次関数で全周期 にわたって近似できると考えられる。すなわち，Mっを 評価指標とするならば, $M^{2}$ 項の係数は正となり, 前述 


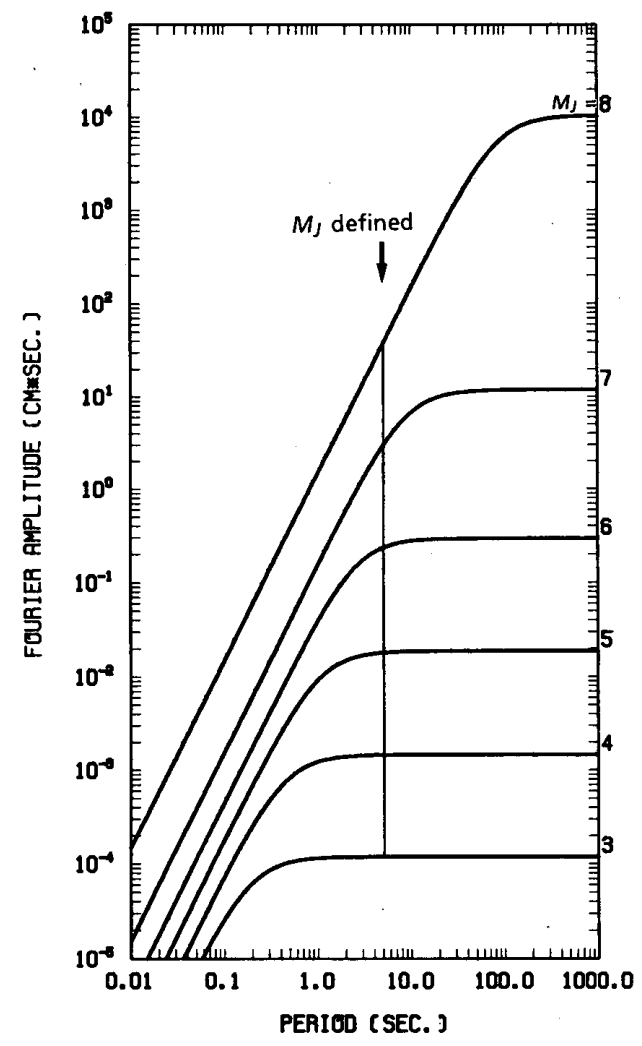

Fig. 3 Source spectrum (Fourier displacement) for earthquakes with various $M_{J}$ at a distance of $100 \mathrm{~km}$.

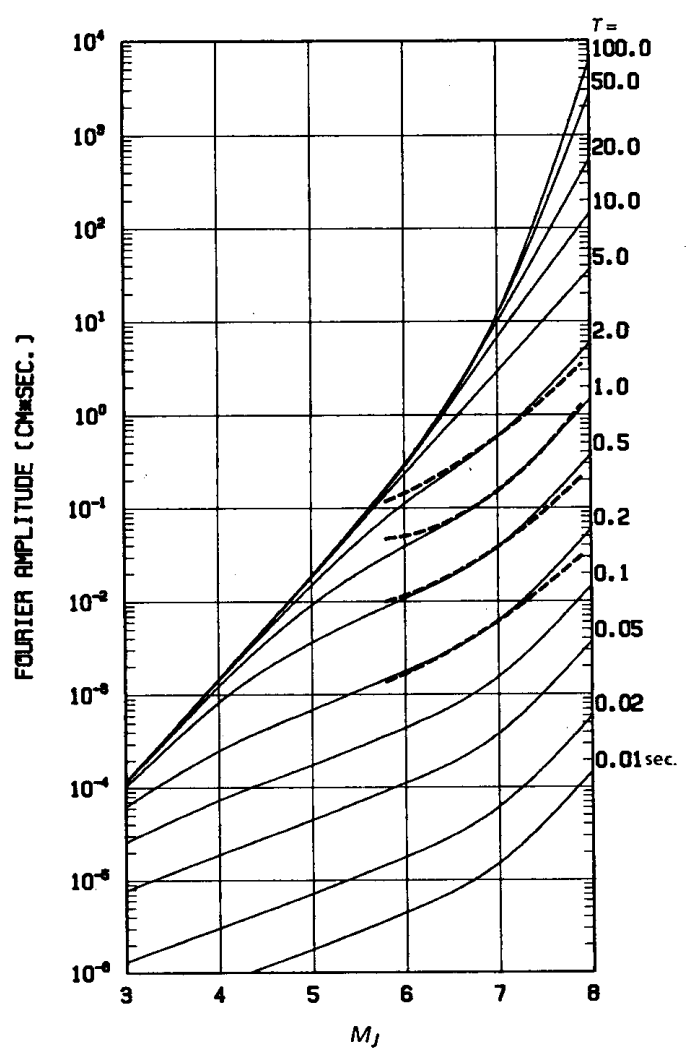

Fig. 4 Relations between $M_{J}$ and the Fourier amplitudes for different periods. Solid and broken lines indicate theoretical relations and the relations derived from regression analysis of the observed records.
の Kamiyama ${ }^{17)}$ による実記録の回帰結果は理論的にも 支持されると言える。

\section{5. 観測記録による検証}

$M_{J}$ による上記のスケーリング則を検証するため，同 一地域で発生した地震を同じ観測点で観測した記録を選 び出した。ただし上記の検討から， $M$ の二次関数で近 似できる $M_{J}>5.5$ の地震に限定した。Table 1 に解析に 用いた観測記録を，またFig. 5 に震源と観測点の位置 を示す。

これらの記録から求めたフーリエスペクトルの山とな る部分を結んで，包絡スペクトルを作り（一例を Fig. 6 に示す), (24) 式のモデルで回帰分析した。

$$
\log A(T)=a_{1}(T) M_{\mathrm{J}}^{2}+a_{2}(T) M_{\mathrm{J}}+\sum d_{i}(T) \cdot l_{i}
$$

ここで, $A(T)$ はフーリエスペクトルの包絡形。同一地 域内の地震の $A(T)$ は震源距離が等しいとして扱えるよ うに，幾何减衰 $\left(X^{-1}\right)$ の距離補正を行って地域内の最大 地震の震源距離に基準化した。震源スペクトルのスケー リングは詳細に見れば地域性をもつと思われるが，ここ では平均的なスケーリングを求めるので各地域の $a_{1}(T), a_{2}(T)$ は共通と考える。 $d_{i}(T)$ は $(5)$ 式の $-b(T) \cdot X-\log X+c(T)$ を観測点ごとに定数項にした もので, $-b(T) \cdot X-\log X$ は距離減衰項であり, $c(T)$ は回帰モデルを $M_{J}$ の二次式に展開したときの $M_{J}$ の 0 次項（定数項）と地盤特性を含む。そして，同地域の地 震を一つの観測点で観測すると, $c(T)$ および距離減衰

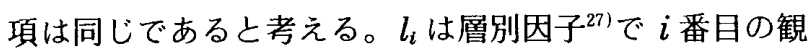
測点のとき 1 , その他のとき 0 とする。ただし, 同じ観 測点でも地震の発生地域が異なれば, 距離が大幅に変わ るので， $d_{i}(T) \cdot l_{i}$ は異なると考える。このようにして， 全データ（19 記録，36 成分）について $M$, の大きさに 依存する回帰係数 $a_{1}(T), a_{2}(T)$ を距離減衰や地盤特性 の影響を除いて抽出した。

得られた $a_{1}(T), a_{2}(T)$ をFig.7に示す。 $a_{1}(T)$ は $a_{2}(T)$ に比べて小さな值となっているが $M_{J}^{2}$ 項にかかる ので, スケーリング則に与える影響は小さくない。また， $a_{1}(T)$ と $a_{2}(T)$ は互いに独立ではなく $a_{1}(T)$ が大きくな れば $a_{2}(T)$ が小さくなる。したがって, $a_{1}(T)$ のわ゙か な変動に依存して $a_{2}(T)$ が大きく変動する。ここで求め た $a_{1}(T), a_{2}(T)$ を用いて, $M_{J}$ の増加にともなうフーリ 工振幅の増加を周期ごとに示したのが Fig. 4 の破線で ある。ただし,（24）式の定数項は震源特性（ $M_{J}$ の二次 式に展開したときの $M_{J}$ の 0 次項）と地盤特性を含み, 精度よく両者を分離できない。したがって, 記録から求 められたスケーリング則は相対的な值なので， $M_{J}=7 て ゙$ 理論値と一致するように縦軸方向に平行移動してある。 理論値も観測値も $M_{J}$ の大きい範囲ではともに下に凸の 
Table 1 List of the records used in the regression analysis

\begin{tabular}{|c|c|c|c|l|}
\hline \multirow{2}{*}{ Region } & \multicolumn{3}{|c|}{ Event } & \multirow{2}{*}{ Observation Station and hypocentral distance (km) } \\
\cline { 2 - 4 } & Origin time & $M_{J}$ & Depth(km) & \\
\hline Tokachi- & $1968,05 / 16,09: 49$ & 7.9 & 20 & Muroran:294, Miyako:190, Shin-ishikari Bridge:325 \\
Oki & $1968,05 / 16,19: 39$ & 7.5 & 20 & Muroran:197, Miyako:214, Shin-ishikari Bridge:225 \\
\hline Miyagi- & $1978,02 / 20,13: 37$ & 6.7 & 50 & Kaihoku Bridge:99 \\
Oki & $1978,06 / 12,17 ; 14$ & 7.4 & 40 & Kaihoku Bridge:91 \\
\hline Urakawa & $1982,03 / 21,11: 32$ & 7.1 & 40 & Tokachi:75 \\
-Oki & $1982,03 / 21,19: 22$ & 5.8 & 40 & Tokachi:71 \\
\hline Nihonkai & $1983,05 / 26,12: 02$ & 7.7 & 14 & Akita:108, Muroran*:270, Aomori:157, Hakodate:211 \\
-Chubu & $1983,06 / 09,21: 49$ & 6.1 & 23 & Akita:115 \\
& $1983,06 / 09,22: 04$ & 6.0 & 14 & Akita:116 \\
& $1983,06 / 21,15: 26$ & 7.1 & 6 & \multicolumn{2}{c}{ Muroran*:201, Aomori:160, Hakodate:155 } \\
\hline
\end{tabular}

* one horizontal component

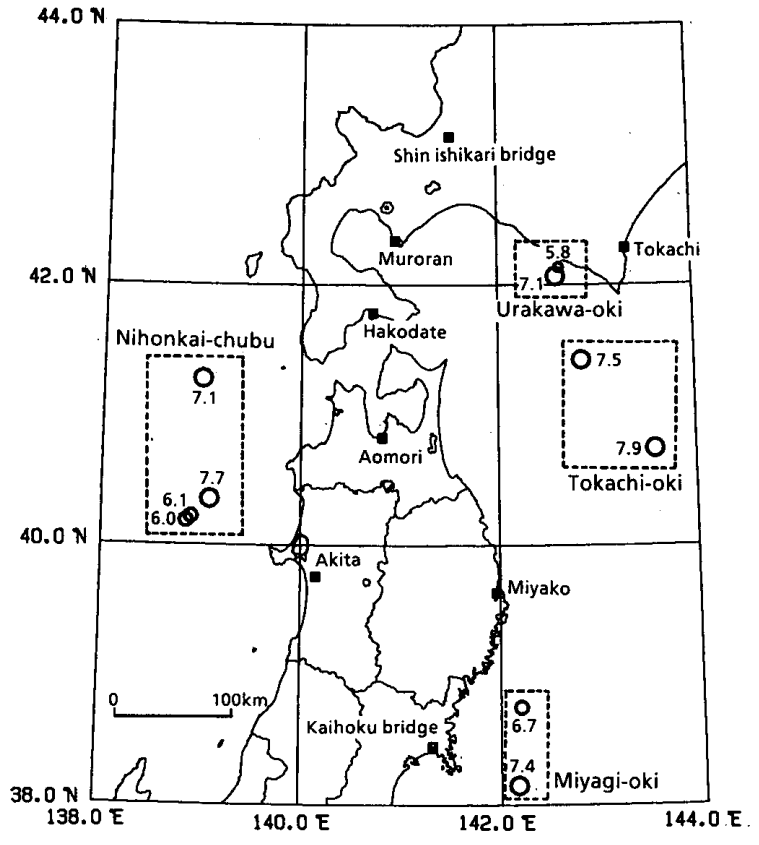

Fig. 5 Map showing epicenters of the events and the observation stations used in the analysis.

曲線となり，よい対応を示す。 $M_{J}$ の項が二次式で表され， かつ $M_{J}^{2}$ 項の係数 $a_{1}(T)$ が正の值をとることは，もし小 地震の波形データを用いて $M_{J}$ の一次式で地震動の評価 式を作ると， $M_{J}$ の大きい範囲での地震動を小さめに見 積もる危険性を示唆するものである。

\section{6. $\boldsymbol{M}_{\boldsymbol{J}}$ と $\boldsymbol{M}_{o}$ の関係}

(23）式の地震モ一メント $M_{o}$ と気象庁マグニチュー ド $M_{J}$ の関係を Table 2 および Fig. 8 に示す。図中の丸 印は，「断層パラメター・ハンドブック」 ${ }^{26)}$ から選んだ 63 地震のデータである。図から， $M_{J}$ にある程度の決定 誤差を考慮すれば, $M_{J}=4$ 程度の比較的小地震から， $M_{J}=8$ クラスの大地震までの $M_{J}$ と $M_{o}$ の関係は. (23) 式による一つの関係式で表現できるといえる。なお，(23) 式に対するデータのばらつきは $M J$ の標準誤差 $(\sigma)$ で

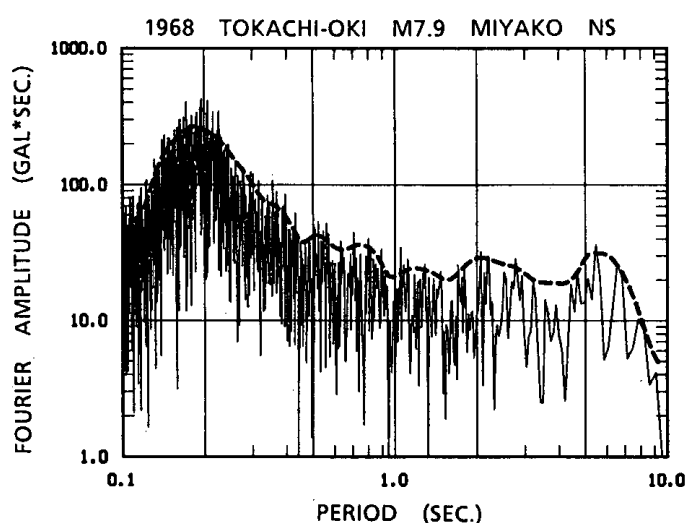

Fig. 6 An example of the Fourier spectra of acceleration record. Broken line indicates the envelope of the spectum.

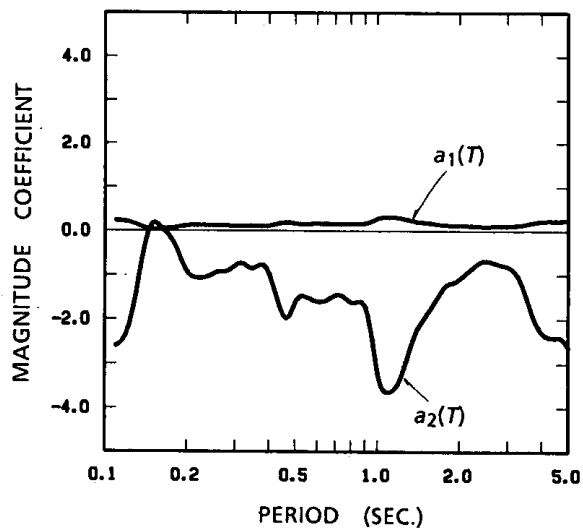

Fig.7 Regression coefficients $a_{1}(T)$ of $M_{J}^{2}$ and $a_{2}(T)$ of $M_{J}$ terms.

\subsection{3 程度である。}

.最近，武村 ${ }^{28)}$ は, Sato ${ }^{221}$ による(11) 式を出発点と して， $M_{J}$ と $M_{s}$ の系統的差を考慮することにより， $M_{J}$

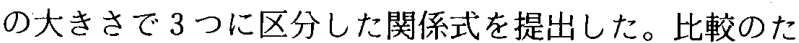
めFig. 8 に Sato および武村の関係式を，それぞれ破線 および鎖線で示した。さらに Takemura et al. ${ }^{291}$ が伊豆 半島周辺で発生する地壳内の小地震に対して求めた関係 式を点線で示した。(23) 式は $M_{J} \geqq 6$ で. Sato $^{22)}$ による 
Table 2 Relation between $\boldsymbol{M}_{\boldsymbol{J}}$ and $\boldsymbol{M}_{\boldsymbol{o}}$ by equation (23)

\begin{tabular}{|c|c|c|c|c|c|c|}
\hline$M_{J}$ & 3 & 4 & 5 & 6 & 7 & 8 \\
\hline$M o$ (dyne $\cdot \mathrm{cm}$ ) & $1.7 \times 10^{21}$ & $2.1 \times 10^{22}$ & $2.7 \times 10^{23}$ & $4.2 \times 10^{24}$ & $1.7 \times 10^{26}$ & $1.5 \times 10^{28}$ \\
\hline
\end{tabular}

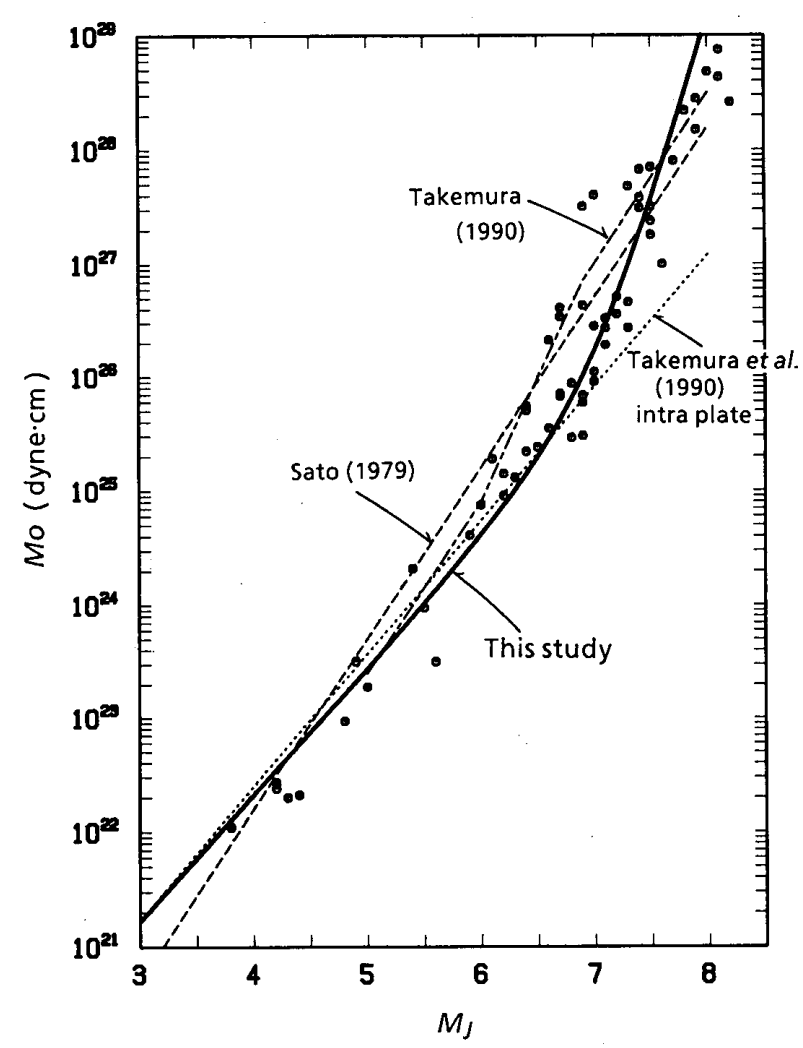

Fig. 8 Relations between $\boldsymbol{M}_{J}$ and $\boldsymbol{M}_{0}$. Circles indicate observed values for individual events. Solid curve is derived in this study. Broken, chained and dotted lines indicate relations derived by Sato (1979), Takemura (1990) and Takemura et al. (1990), respectively.

（11）式に比べて $M_{J}$ に対する $M_{o}$ の増加が著しい。ま た Takemura et al. の地壳内地震に対する関係式の導出 には，主に $M_{J}$ が 3〜 5 の小地震のデータが使われてお り， $M_{J}$ の小さい範囲での信頼性が高いが，(23）式は $M_{J}$ の小さい範囲で Takemura et al. の関係式とよく一 致する。

また，武村 ${ }^{28)}$ によれば地款内地震の震源深さはほぼ $15 \mathrm{~km}$ より浅いので, 表面波の励起により $M_{J}$ が大きく 評価される可能性を指摘している。そこで $15 \mathrm{~km}$ 以浅 の 40 地震と, $15 \mathrm{~km}$ より深い 23 地震で場合分けして回 帰しなおしてみた。15 km 以浅のデータでは， $M_{J}$ の係 数は 1.10 , 定数項は $17.91 。 15 \mathrm{~km}$ より深いデータでは $M_{J}$ の係数は 108 , 定数項は 18.14 で，ともに震源深さ で場合分：しても $95 \%$ 信頼限界内に収まることがわ かった。

\section{7.まとめ}

距離減衰式に代表される地震動評価式において，マグ ニチュード項は $M$ の一次式または二次式で近似される
が，その理論的背詈は明確でなかった。本研究では, 震 源スペクトルに関する $\omega^{-2}$ の震源モデルにもとづいた $M_{J}$ によるスペクトルのスケーリング則の検討から， $M_{J}$ の大きさによるスペクトル振幅の変化は複雑な関数とな るが， $M_{J} 5.5$ 程度以上についてはほぼ $M_{J}$ の二次式で近 似できることを示した。さらに，日本の代表的な四つの 大地震の観測記録を用いて $M_{J}^{2}$ 項を導入した評価式によ りマグニチュード係数を求め, 理論的スケーリング則と

よく調和することを検証した。

また，検討の過程で求められた新たな $M_{J}$ と $M_{o}$ の関 係式は， $M_{J}=4.0$ 以上の日本の地震デー夕をよく説明す ることがわかった。

\section{謝 辞}

本研究で用いた強震記録は運輸省港湾技術研究所 ${ }^{30}$ お よび建設省土木研究所 ${ }^{311}$ より公表された記録波形に対し て, 後藤・亀田・杉戸・今西 ${ }^{32}$ による基線および計器特 性補正を施した補正加速度波形である。また本研究を進 めるにあたり, 鹿島建設株式会社小堀研究室の武村雅之 博士より，未公表論文のコピーを頂いた。ここに記して 厚く謝意を表します。

\section{参考文献}

1）木下繁夫：表層地盤の減衰特性に関する考察，土木学会 論文報告集，第 330 号，pp. 15～25，1983.

2) Fukushima, Y., S. Kinoshita and H. Sato : Measurement of $Q^{-1}$ for $S$-waves in mudstone at Chikura, Japan : Comparison of incident and reflected phases in borehole seismograms, Bull. Seism. Soc. Amer. (submitted)

3) Abrahamson, N.A. and J. J. Litehiser: Attenuation of vertical peak acceleration, Bull. Seism. Soc. Amer. 79, pp. $549 \sim 580,1989$.

4) Fukushima, Y. and T. Tanaka: A new attenuation relation for peak horizontal acceleration of strong earthquake ground motion in Japan, Bull. Seism. Soc. Amer. 80, pp. $757 \sim 783,1990$.

5) Aki, K. : Scaling law of seismic spectrum, J. Geophys. Res., 72, pp. 1217 1231, 1967.

6) Kanamori, H. and D. L. Anderson: Theoretical basis of some empirical relations in seismology, Bull. Seism. Soc. Amer. 65, pp. 1073 1095, 1975.

7) Geller, R. J. : Scaling relations for earthquake source parameters and magnitude, Bull. Seism. Soc. Amer. 66, pp. 1501 1523, 1976.

8) Joyner, W. B. : A scaling law for the spectra of large earthquakes, Bull. Seism. Soc. Amer: 74, pp.1167 1188, 1984.

9) McGuire, R. K., A. M. Becker and N.C. Donovan : Spectral estimates of seismic shear waves, Bull. Seism. Soc. Amer. 74, pp. 1427 1440, 1984.

10) Boore, D. M. : Short-period P. and S-wave radiation from large earthquakes : Implications for spectral scaling relations, Bull. Seism. Soc. Amer. 76, pp. 43 64, 
1986.

11) Irikura, $K:$ Prediction of strong acceleration motions using empirical Green's function, Proc. 7th Japan Earthquake Engineering Symposium, pp.151 156, 1986.

12) Dan, K., T. Watanabe and T. Tanaka: A semiempirical method to synthesize earthquake ground motions based on approximate far-field shear-wave displacement, J. Structural and Construction Engineering (Transactions of AIJ), No.396, pp. 27 36, 1989.

13) Hiehata, S., M. Takemura, and T. Ohta: Regression analysis on Fourier amplitude spectra of seismic ground motions in terms of earthquake magnitude, hypocentral distance and site condition, Proc. 9th World Conf. on Earthquake Engineering, Tokyo, Japan, 2, pp.319 $324,1988$.

14) Joyner, W. B. and D. M. Boore : Peak horizontal acceleration and velocity from strong-motion records including records from the 1979 Imperial Valley, California, earthquake, Bull. Seism. Soc. Amer. 71, pp.2011 $2038,1981$.

15）翠川三郎：小地震の加速度包絡波形の合成による大地震 の最大加速度の推定, 日本建築学会論文報告集, 第 398 号, pp. 23 30, 1989.

16) Papageorgiou, A.S. and K. Aki : A specific barrier model for the quantitative description of inhomogeneous faulting and the prediction of strong ground motion. I. description of the model, Bull. Seism. Soc. Amer. 73, pp. 693 722., 1983.

17) Kamiyama, M. : Earthquake source characteristics inferred from the statistically analyzed spectra of strong motions with aid of dynamic model of faulting, Structural Eng. /Earthquake Eng. (Proc. Japan Society of Civil Engineers), No. 386, pp. 391s 400s, 1987.

18) Trifunac, M. D. : Preliminary empirical model for scaling Fourier amplitude spectra of strong ground acceleration in terms of earthquake magnitude, source-to-station distance, and recording site conditions, Bull. Seism. Soc. Amer. 66, pp. 1343 1373, 1976.
19) Brune, J.N. : Tectonic stress and the spectra of seismic shear waves from earthquakes, J. Geophys. Res., 75, pp. 4997 5009, 1970.

20) Savage, J.C. : Relation of corner frequency to fault dimensions, J. Geophys. Res., 77, pp. 3788 3795, 1972.

21) Sato, T. and T. Hirasawa: Body wave spectra from propagating shear cracks, J. Phys. Earth, 21, pp. 415 431, 1973.

22) Sato, R. : Theoretical basis on relationships between focal parameters and earthquake magnitude, J. Phys. Earth, 27, pp. 353 372, 1979.

23) Kanamori, H. : The energy release in great earthquakes, J. Geophys. Res.; 82, pp. 2981 2987, 1977.

24）坪井忠二：地震動の最大振幅から地震の規模 $M$ を定める ことについて, 地震 II, 7, pp. 185〜193, 1954.

25) Hisada, T. and H. Ando : Relation between duration of earthquake motion and the magnitude, Kajima Institute of Construction Technology, 1976.

26）佐藤良輔：日本の地震断層パラメータ・ハンドブック, 鹿島出版会, 1989.

27) Draper, N.R. and H. Smith : Applied Regression Analysis, Wiley, New York, 1966.

28）武村雅之：日本列島およびその周辺地域に起こる浅発地 震のマグニチュードと地震モーメントの関係, 地震 II , 43, pp. 257 265, 1990.

29) Takemura, M., T. Ikeura and R. Sato: Scaling relations for source parameters and magnitude of earthquakes in the Izu peninsula region, Japan, Tohoku Geophys. Journ. (Sci. Rep. Tohoku Univ., Ser. 5), 32, pp.77$89,1990$.

30）運輸省港湾技術研究所：港湾技研資料 80 458 号， 1963 - 1983.

31）建設省土木研究所：土木研究所資料 33 号, 1978.

32）後藤尚男, 龟田弘行, 杉戸真太, 今西直人：ディジタルフィ ルターによる SMAC-B 2 型加速度計記録の補正につい て, 土木学会論文報告集, No. 277, pp. 57〜69, 1978.

(1990 年 8 月 13 日原稿受理, 1991 年 5 月 1 日採用決定)

\section{英文要約（Summary）}

In most of the former studies of the attenuation relation, the increasing amplitude of the earthquake ground motion with earthquake magnitude was expressed by the linear relation of the magnitude. However, when the $\omega^{-2}$ model is assumed, the corner period of the spectrum varies with the magnitude, and the scaling law of the source psectrum amplitude becomes a complicated function of magnitude. Based on the $\omega^{-2}$ model, a relation between $M_{o}$ and $M_{J}$ was derived from the data of 63 events whose $M_{J}$ are ranging from 3.9 to 8.2. Further, the theoretical scaling law of the source spectrum obtained from the relation was approximated with the $M_{J}^{2}$ term of the attenuation relation. This approximation was confirmed from the strong-motion accelerograms from the large events occurred in the northern Japan. 